\title{
CAPACITY BUILDING OF STATE ELEMENTARY SCHOOL 206 TEACHER GROUPS IN IMPLEMENTING THE BANDUNG MASAGI PILAR LOVE FOR THE ENVIRONMENT PROGRAM IN THE CITY OF BANDUNG
}

\author{
Imas Sumiati $^{1}$, Hari Busthomi Ariffin ${ }^{2}$, Yayan Mulyana ${ }^{3}$ \\ ${ }_{1,2,3}$ Administrasi Negara, Universitas Pasundan,Indonesia \\ 1'Imas.sumiati@unpas.ac.id, ${ }^{2}$ hari.bustomi@unpas.ac.id, ${ }^{3}$ yayan.mulyana@unpas.ac.id
}

\begin{abstract}
The partners that will be chosen by the implementing team are teachers who teach at SMA 206 Putraco Indah, Bandung. Partners were chosen because they have not fully implemented the Bandung City government program "Bandung Masagi Pillar of Love for the Environment" as an effort to reforest and organize school environments in the City of Bandung.The problem faced by partners is the unavailability of funds in implementing the program and environmental management has not been fully implemented, especially at the back of the school, besides that teachers have difficulties related to methods in educating students because almost $75 \%$ of students with special needs are instilling knowledge of Environmental Education (PLH). Students not only memorize theory, but are also able to implement their knowledge in daily behavior and character. The solution is carried out through the guidance of making thematic Learning Preparation Plans. The training providers are carried out by BPLH and PGSD UNPAS, namely by providing training on making environmental thematic RPP, implementing school greening and cleaning school facilities. Mentoring is expected to improve the ability of teachers in preparing PLH RPP for elementary school students so that it is more attractive to students.Teachers are expected to create interesting PLH learning modules and increase the attractiveness of the environment to students' daily lives. Another problem faced by the two elementary schools is the problem of cleaning facilities that are not in accordance with health standards.PKM provides solutions in improving hygiene facilities and empowering teachers and students in maintaining gardens, composters and waste banks. The program of activities begins with the preparation of lesson plans for elementary school (SD) teachers and is thematic in nature. Structuring the school environment can create a beautiful, cool, clean, healthy atmosphere in supporting the process of implementing KBM. A conducive school environment is needed to support a comfortable learning process so as to encourage the realization of a quality lifestyle in increasing educational productivity.
\end{abstract}

Keywords: environmental management, reforestation, PLH (environmental education), RPP (learning implementation plans, thematics, cleanliness).

\section{A. Introduction}

In Indonesia, substantially Environmental Education (PLH) has been initiated since 1975. The government has officially determined that PLH material is delivered to students in an integrative way on relevant subjects. For Elementary 
Schools, PLH materials are integrated into Religious Education, PPKn, Physical Education, Natural Sciences, and Social Studies subjects from Class I to Class VI. As curricular content. In SMA and SMK, PLH material or content is also integrated into science, social studies and other subjects. One form of PLH implementation that is carried out programmatically in schools is the "Bandung Masagi Pillar of Love for the Environment" program. In Bandung this program was promoted by the mayor of Bandung. MP (2020)

Bandung Masagi contains four main principles of Sundanese people in practicing life, namely penance asih (humanity), silih sharpening (educating), penance asuh (accompaniment), and reparation wawangi (delivering positive things). These four principles are embodied in four main programs, namely love of religion, protecting culture, defending the country, and loving the environment.form a person's character to be physically strong by eating nutritious food, intelligent because he is fed with knowledge and morals through spiritual intake. Hsu (2004)

The Bandung Masagi character education model is a concrete form of mental revolution so that the children of Bandung have a root footing in local wisdom and competence in the $21 \mathrm{st}$ century, because the condition is facing a new era. Yustiani, YM, Rusmaya, D., Hasbiah, AW, Rachman (2014). This is in accordance with the conditions in Bandung which continues to develop and is accompanied by competent Human Resources (HR), while Bandung Masagi's goal is to form a person's character to be strong by consuming nutritious, intelligent food because he is fed with knowledge and morals through spiritual intake. Yustiani, YM (2015).

\section{B. Method Of Implementation}

Through the results of interviews with the principal, it was revealed that the Problems of Partners Observation visually when the service proposer team visited the school location, showed that:

1. No funds for reforestation,

2. There is no special manager for that field,

3. There is no RPP for reforestation

4. Land behind the school that is not maintained and lacks greenery 
5. Lack of basis for healthy living behavior.

6. There are teachers who have passed S1 but are still not linear, so they have not been certified

7. Many students with special needs (ABK).

Based on the analysis of the situation, the Implementation Team justifies the priority problems of partners as follows:

1. No funds for reforestation

2. There is no RPP for reforestation

3. Difficulty of methods in educating children with special needs

This research was conducted using a qualitative approach. This research begins with interviews with Partners, identifies Partner problems, prioritizes Partner problems, justifies Partner problems, carries out the stages of preparation, implementation, and evaluation of activities, seeks the sustainability of the program of activities.

Based on the stages of implementing partner activities in accordance with the priority issues being handled, the approach method is to facilitate the application of reforestation funds to the government/related agencies, facilitate reforestation efforts, as well as training methods, where in this activity the Implementing Team provides Online Learning Training in the Pandemic Period, assisted by experienced instructors in their fields.

\section{Result And Discussion}

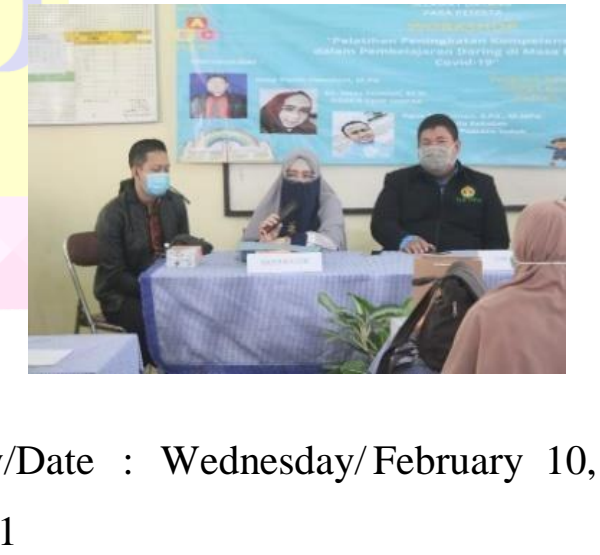

Documentation : Mrs. Dr. Imas sumiati M.Si is opening the event as well as providing direction to participants in the continuity of training activities to increase teacher competence in online learning during the Covid pandemic. 


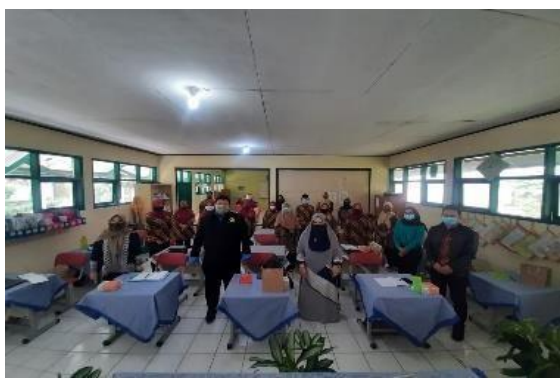

Day/ Date : Wednesday/ February 10, 2021

Documentation: all participants who take part in training activities to increase teacher competence in online learning during the Covid-19 pandemic

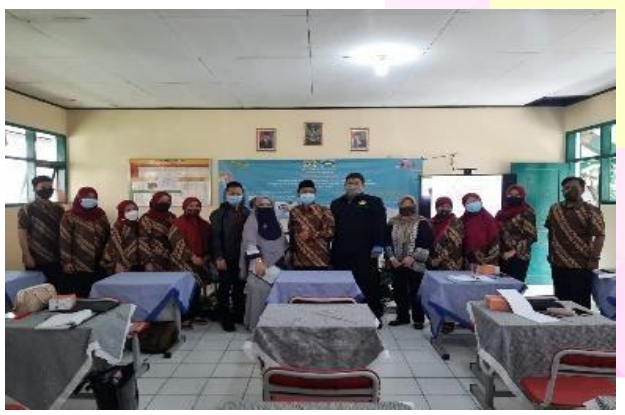

Day/ Date : Wednesday/ February 10, 2021 Documentation : Teachers and Staff of the 206 Putraco Indah State Elementary School, the place for PKM Training activities Improving Teacher Competence inOnline Learning During the Covid-19 Pandemic.

\section{Conclusion}

In this PKM activity it involves teachers and also administration in its implementation so that this activity, especially when presenting resource persons, is very attractive and also fun, in this activity the author also presents and invites other schools, namely STATE ELEMENTARY SCHOOL (SDN) Batununggal as participants while the authors present from Unpas environment itself is a lecturer at FKIP who is competent in the field who is accustomed to creating online learning problem content.

The participants were very enthusiasticand carried out the training carefully, which did not teach only assignments from books, now they can face to face with students even though they are virtual.In the future, schools must synergize with local governments, not 
only with the education office but with all levels of society and other skpd as a coordination mechanism that the implementation of education is a joint task, not only the task of the education office so that in the future it will be integrated comprehensively. Hayward, (2014).

\section{E. REFERENCES}

Hayward, B. (2014). Children, Citzen, and Environment: Nurturing a Democratic Imagination in a Changing World. The Journal Environmental Education, 45(2).

Hsu, S.-J. (2004). The Effect of an Environmental Education Program on Responsible Environmental Behavior and Associated Environmental Literacy Variables in Taiwanese

College Students. The Journal of Environmental Education, 35(2).

MP,S. (2020). Saatnya Reorientasi Pendidikan Menuju Efsd. http://vedca.siap.web.id/\%0A, https://disdik.bandung.go.id/ver3/pen didikan-karakter-bandung masagi/\%0A
Yustiani, Y.M., Rusmaya, D., Hasbiah, A.W., Rachman, I. (2014). Efektifitas Pelajaran Pendidikan Lingkungan hidup Sebagai Penyiapan Generasi Sadar Lingkungan. AL Mizan.

Yustiani, Y.M., R. (2015). Laporan Workshop Uji Coba RPP Pendidikan Lingkungan Hidup di SD Pertiwi dan SEKOLAH DASAR NEGERI (SDN) Pelesiran. 